\title{
The effects of activated charcoal on growth, ruminal characteristics and blood profiles in growing sheep
}

\author{
H Tobioka, EP Garillo, R Pradhan
}

Kyushu Tokai University, School of Agriculture, Choyo-son, Aso-gun, Kumamoto 869-14, Japan

The feeding schemes with concentrate-based ration aimed at a quality carcass has brought some diseases and clinical disorders to animals (Motoi, 1988, J Jpn Grassi Sci, Appl Ver, 10, 24-31). The use of some feed additives which might reduce the mortality of animals proved to have a possibility for the residues in liver and meat after slaughtering (Honikel et al, 1978, J Anim Sci, 61, 12221227). The activated charcoal (AC) was an alternative additive tried by some beef operators in Japan. Preliminary experiments on AC conducted by Tobioka et al (1994, West Jpn J Anim Sci, 37, 48-53) showed an improved feed conversion ratio (FCR) in beef cattle. In the present study, the effects of $A C$ were investigated in growing animals.

Twelve growing sheep were divided into 3 groups. Concentrate-based diet were offered to animals for 9 weeks. The $A C$ was given to three groups of animals at the rate of $0,0.5$ or $1.0 \%$ of the feed dry matter offered which was equivalent to $2.8 \%$ of the body weight. Growth parameters, ruminal characteristics and blood profiles were measured.
The $A C$ in diets seemed to affect daily weight gain (DG) and FCR of the animals. The ruminal $\mathrm{pH}$ and protozoa count showed increased tendency for AC groups. The ruminal ammonia- $\mathrm{N}$ tended to be lower in only one of AC groups (Garillo and Tobioka, 1995, Asian Aust $\mathrm{J}$ Anim Sci, 8, in press). The molar ratios of acetate to propionate (C2/C3) tended to decrease by $1.0 \% A C$ both before and $4 \mathrm{~h}$ after feeding. Serum total protein, glucose (Glu) and total cholesterol were very similar among treatments. However, blood urea nitrogen (BUN) tended to be low in $0.5 \% \mathrm{AC}$ diet corresponding to the low ruminal ammonia. Serum GOT, GPT and alkaline phosphatase (Al-P) activities of treated groups decreased or tended to decrease as compared to reference one. Creatine phosphokinase (CPK) also tended to decrease by $A C$ diet after feeding.

In conclusion, the addition of $\mathrm{AC}$, especially at $1.0 \%$, seemed to have some effects on growth, ruminal and blood characteristics, especially on some serum enzyme activities of animal fed on concentrate-based diet.

\begin{tabular}{|c|c|c|c|c|c|c|c|c|c|}
\hline \multirow[t]{2}{*}{$\mathrm{AC}$ rate $(\%)$} & \multirow[t]{2}{*}{$D G(\mathrm{~kg})$} & \multirow[t]{2}{*}{ FCR } & \multicolumn{3}{|c|}{ Rumen fluid (4 h) } & \multirow[b]{2}{*}{$\begin{array}{c}\text { Glu } \\
(\mathrm{mg} / \mathrm{dl})\end{array}$} & \multicolumn{2}{|c|}{ Serum $(4 h)$} & \\
\hline & & & $\overline{\mathrm{pH}}$ & $\begin{array}{c}\text { Protozoa } \\
\left(10^{4} / \mathrm{ml}\right)\end{array}$ & $\mathrm{C} 2 / \mathrm{C} 3$ & & GPT & $\begin{array}{l}\text { Al-P } \\
(\mathrm{IU} / \mathrm{I})\end{array}$ & CPK \\
\hline 0 & 0.22 & 5.81 & 6.42 & 126 & 2.75 & 80.5 & 19.0 & $648 \mathrm{a}$ & 290 \\
\hline 0.5 & 0.24 & 5.15 & 6.69 & 140 & 3.16 & 84.0 & 15.0 & $375^{b}$ & 233 \\
\hline 1.0 & 0.25 & 5.16 & 6.57 & 137 & 2.41 & 81.3 & 16.8 & $549 a$ & 217 \\
\hline
\end{tabular}

